\title{
熱間鍛造用型鋼の高温破面解析 ${ }^{\dagger}$
}

$$
\begin{array}{lllll}
\text { 江原隆一郎* } & \text { 山 田義 } & \text { 和** } \\
\text { 山田 } & \text { 保** 窪 } & \text { 田勝 } & \text { 昭*** }
\end{array}
$$

\section{Fractography of High Temperature Fracture Surface of Hot Forging Die Steel}

by

\author{
Ryuichiro Ebara*, Yoshikazu YamadA**, Tamotsu YamadA** \\ and Katsuaki KuBota***
}

In order to investigate the high temperature fracture behavior of hot forging die steel, low cycle fatigue life and crack propagation tests of SKD62 were carried out. The effects of testing temperature, hardness of base metal and surface hardening treatments such as ion nitriding, tuftriding and sul-surf treatment on low cycle fatigue strength and crack propagation rate were investigated.

Decrease of low cycle fatigue strength and increase of crack propagation rate were comparatively prominent at $450^{\circ} \mathrm{C}$. Increase of hardness of base metal was most effective to improve the low cycle fatigue strength of SKD62 due to delay of crack initiation. Among various surface treatments, ion nitriding was most effective to improve the low cycle fatigue strength of SKD62.

Striation was predominant in the fracture surfaces of all low cycle fatigue tested specimens in this experiments.

Thermal fatigue crack initiation and propagation tests were also conducted by heating specimens up to $1000^{\circ} \mathrm{C}$ by use of a laboratory made thermal fatigue testing machine. By lowering the temperature difference between heating and cooling, crack initiation life was increased and crack propagation rate was decelerated. Striation like pattern appeared remarkably on the thermal fatigue fracture surface. The same type of fracture surface was observed on the thermal fatigue failed fracture surface of hot forging die.

キー・ワード : 熱間鍛造用型鋼, 低サイクル疲労, 熱疲労き裂発生, き裂進展

\section{1 緒言}

熱間鍛造用金型は表層部に 生じた機械的な 繰返し 応力による疲労あるい熱応力の絽返しによる疲労き 裂から衝撃的に破壊することが多いにもかかわらず, 型鋼の疲労拉よび熱疲労に関する基礎的な知見は少な く, 破面形態関する情報も非常に少ない, 著者らは これまで熱間鍛造用型鋼の計装化衝撃試験を行い動 的破壞じん性值とストレッチゾーン幅との関係および 低サイクル疲労強度に及活す表面硬化処理に関し検討 し破面の特徵を把握した. 本研究では, さらに同鋼の 低サイクル疲労強度および疲労き裂進展速度に及ぼす 試験温度, 硬さ拉よび各種表面硬化処理の影響を把握 し，また熱疲労挙動について実験的に検討したのでそ の結果について報告する.

\section{2 実 験 方 法}

\section{$2 \cdot 1$ 供試材および試験片}

供試材としては SKD 62 相当鋼を用いた. 化学組 成および機械的性質を Table I に示す. Table I 中 の同鋼(1)(2)を低サイクル疲労試験に，また同鋼(3)を熱 疲労試験にそれぞれ用いた。低サイクル疲労試験片の 形状と寸法を Fig. 1 に示す. 疲労寿命試験には丸棒 切欠き試験片（Kt=1.31）を用いた．き裂進展試験に は片側に半径 $5 \mathrm{~mm}$ の切欠き加工後切欠き底に幅 0.2 $\mathrm{mm}$, 長さ $5 \mathrm{~mm}$ のスリットを插入した平板試験片 を使用した. Fig. 2 亿熱疲労試験片の形状と寸法を示 す。裂発生試験には試験片の片面中央にあらかじめ 深さ $1.52 \sim 4.22 \mathrm{~mm}$, 幅 $0.37 \sim 0.41 \mathrm{~mm}$ の人工切欠 きを放電加工により挿入した平板試験片を用いた。一 一 方き裂進展試験には $1 \mathrm{CT}$ 試験片を使用し, 油圧疲労 試験機を用いて試験速度 $20 \mathrm{~Hz}$, 応力比 $\left(\sigma_{\min } / \sigma_{\max }\right)$

$\dagger \quad$ 原稿受理 昭和61年8 月12日 Received Aug. 12, 1986

* 正会員 三菱重工業(株)広島研究所 広島市西区観音新町, Hiroshima R \& D Center, Mitsubishi Heavy Industries, Ltd., Kan-onshin-machi, Nishi-ku, Hiroshima

** 三菱重工業(株)広島研究所 広島市西区観音新町, Hiroshima R \& D Center, Mitsubishi Heavy Industries, Ltd., Kan-on-shin-machi, Nishi-ku, Hiroshima

*** 三菱自動車工業(株)東京製作所 川崎市中原区大倉町, Tokyo Motor Vehicle Works, Mitsubishi Motors Corp., Ohkura-cho, Nakahara-ku, Kawasaki 
Table I. Chemical compositions and mechanical properties of tested steel.

\begin{tabular}{|c|c|c|c|c|c|c|c|c|c|c|c|c|c|c|c|}
\hline \multirow{2}{*}{$\begin{array}{l}\text { Mate- } \\
\text { rial }\end{array}$} & \multicolumn{9}{|c|}{ Chemical compositions (\%) } & \multicolumn{6}{|c|}{ Mechanical properties } \\
\hline & $\mathrm{C}$ & $\mathrm{Si}$ & $\mathrm{Mn}$ & $\mathrm{P}$ & $\mathrm{S}$ & $\mathrm{Cr}$ & W & Mo & $\mathrm{V}$ & $\begin{array}{c}\text { Temp. } \\
\left({ }^{\circ} \mathrm{C}\right)\end{array}$ & $\left(\begin{array}{c}\sigma_{0.2} \\
(\mathrm{MPa})\end{array}\right.$ & $\left.\begin{array}{c}\sigma \\
(\stackrel{B}{\mathrm{P}} \mathrm{a}\end{array}\right)$ & $\stackrel{\varepsilon}{\varepsilon})$ & $(\%)$ & $\mathrm{HRC}$ \\
\hline $\begin{array}{l}\text { SKD } \\
\quad 62(1)^{* 1)}\end{array}$ & 0.40 & 1.04 & 0.43 & 0.021 & 0.010 & 4.98 & 1.02 & 1.22 & 0.38 & $\begin{array}{r}\text { R. T } \\
200 \\
450 \\
500\end{array}$ & $\begin{array}{r}1149.3 \\
1081.7 \\
894.4 \\
793.4\end{array}$ & $\begin{array}{r}1368.0 \\
1276.8 \\
1069.9 \\
957.1\end{array}$ & $\begin{array}{r}12.5 \\
9.5 \\
16.0 \\
14.5\end{array}$ & $\begin{array}{l}42.2 \\
35.2 \\
63.9 \\
70.9\end{array}$ & $\begin{array}{l}43.5 \\
- \\
- \\
-\end{array}$ \\
\hline $\begin{array}{l}\text { SKD } \\
62(2)^{* 2)}\end{array}$ & 0.36 & 0.99 & 0.40 & 0.020 & 0.006 & 4.90 & 1.07 & 1.26 & 0.24 & $\begin{array}{r}\text { R.T } \\
200 \\
450 \\
500\end{array}$ & $\begin{array}{r}1359.2 \\
1227.8 \\
1002.2 \\
896.3\end{array}$ & $\begin{array}{l}1571.0 \\
1453.3 \\
1222.9 \\
1122.9\end{array}$ & $\begin{array}{r}5.5 \\
6.5 \\
13.0 \\
14.0\end{array}$ & $\begin{array}{r}7.8 \\
18.1 \\
48.2 \\
55.7\end{array}$ & $\begin{array}{l}46 \\
- \\
- \\
-\end{array}$ \\
\hline $\begin{array}{l}\text { SKD } \\
\left.62(3)^{*} * 3\right)\end{array}$ & 0.36 & 0.90 & 0.44 & 0.020 & 0.005 & 5.19 & 1.09 & 1.26 & 0.25 & R. T & 1069.9 & 1318.0 & 15.5 & 38.8 & 43 \\
\hline
\end{tabular}

Note; *1) $1010^{\circ} \mathrm{C} \times 1.3 \mathrm{Hr} \mathrm{A.C,} 600^{\circ} \mathrm{C} \times 5 \mathrm{Hr}$ A.C

*2) $1010^{\circ} \mathrm{C} \times 1.3 \mathrm{Hr}$ A.C, $585^{\circ} \mathrm{C} \times 5 \mathrm{Hr}$ A.C

*3) $1000^{\circ} \mathrm{C} \times 1.3 \mathrm{Hr} 0 . \mathrm{Q}, 550^{\circ} \mathrm{C} \times 7 \mathrm{Hr} \mathrm{A} . \mathrm{C}$

R.T Room temperature

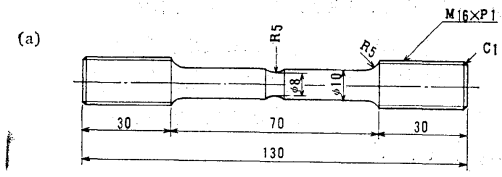

(b)

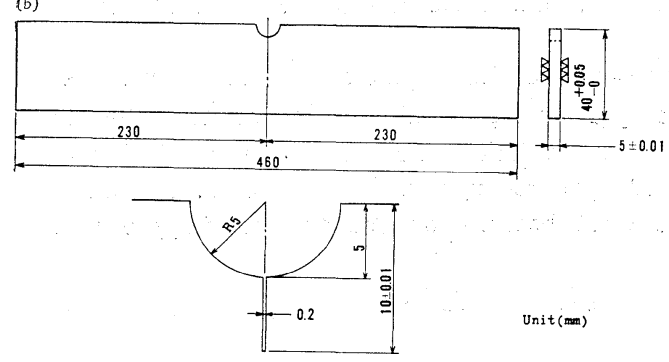

(a) For fatigue life test.

(b) For crak propagation test.

Fig. 1. Low cycle fatigue test specimen.

$=0.1$ の条件で疲労予き裂を挿入した後，同予き裂を 残して試験片を切断し試験に供した.

\section{$2 \cdot 2$ 試験方法}

低サイクル疲労試験は油圧疲労試験機 (10 Ton) に より試験速度 $0.083 \mathrm{~Hz}$, 応力比 $\left(\sigma_{\min } / \sigma_{\max }\right)=0.05$ の条件で実施した、試験温度は室温, $200^{\circ} \mathrm{C}$ 和よび 450 ${ }^{\circ} \mathrm{C}$ とし 200 および $450^{\circ} \mathrm{C}$ の試験には赤外線急速加熱装 置を用いた。なおき裂進展試験時のき裂長さは各繰返 乙数ごとに試験機を止めて読取顕微鏡（20倍）により 測定した. 一方熱疲労試験には本研究のため特に試作 した熱疲労試験装置 (Fig. 3) を用い加熱, 冷却の熱 サイクルを試験片に与えることにより実施した。本装 置は大別して酸素, LPG ガスから成る加熱帯と, 加 熱帯の温度を一定に保つために設けた温度制御装置抒 よび試験片を急冷する冷却帯から構成されて扣り，冷 却媒体としては水道水を使用した. 加熱温度は $200^{\circ} \mathrm{C}$, $400^{\circ} \mathrm{C}, 600^{\circ} \mathrm{C}, 800^{\circ} \mathrm{C}$ およ゙ $1000^{\circ} \mathrm{C}$ ぜあり加熱帯で加 熱後, 冷却ノズルから水道水を噴射することにより試 (a)

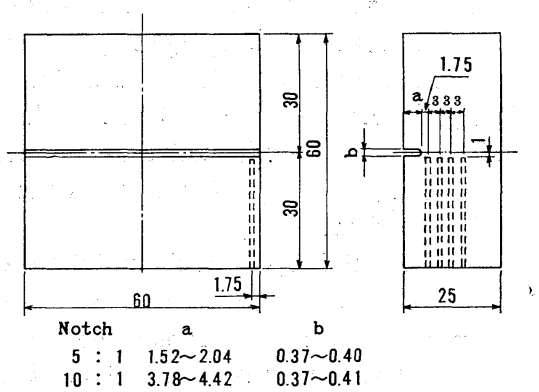

(b)

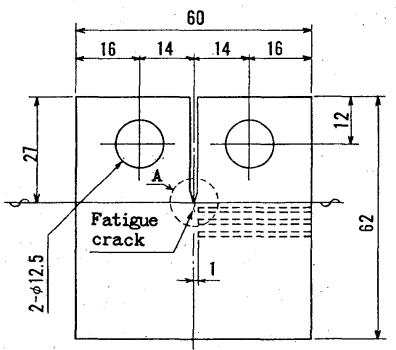

Fatigue crack length $=1.52 \sim 3.11$

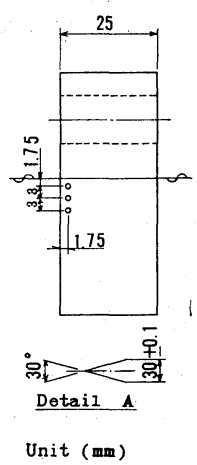

(a) For crack initiation test.

(b) For crack propagation test.

Fig. 2. Thermal fatigue test specimen.

験片表面に加熱，冷却のサイクルを与えることができ る.な执試験片表面の温度を測定することが困難であ るのであらかじめ試験片に熱電対穴を加工し，き裂発 生試験片では人工切欠き底をまたき裂進展試験片は疲 労予き裂先端部の温度を測定し試験温度とした（Fig. 2 (b)の点線部). 疲労試験打よび 熱疲労試験後の破面 はSEM (JSMP-15) にて詳細に観察した。

\section{3 実験結果および検討}

\section{$3 \cdot 1$ 低サイクル疲労試験結果}

SKD62 (1)，(2)鋼の室温， $200^{\circ} \mathrm{C}$ 执よび $450^{\circ} \mathrm{C}$ に护 


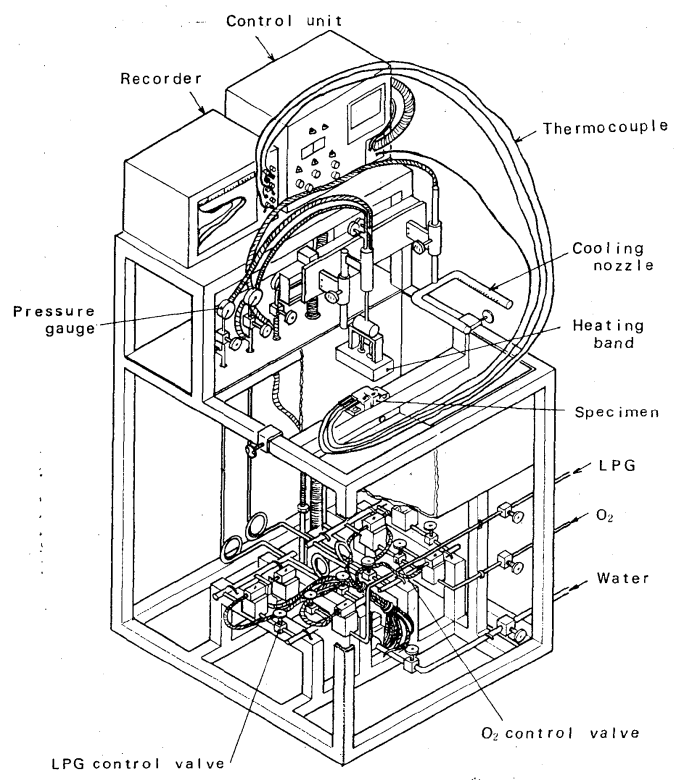

Fig. 3. Schema of laboratory made thermal fatigue testing machine.

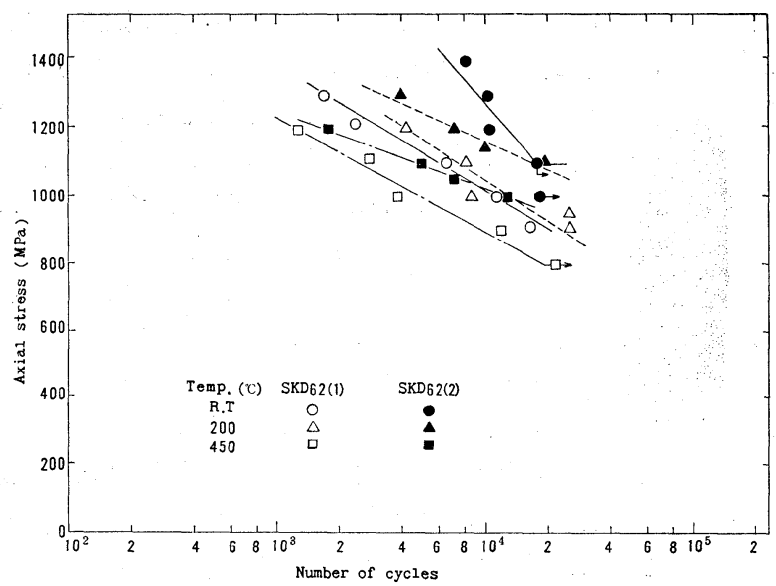

Fig. 4. S-N diagrams of SKD62 (1) and SKD62 (2).

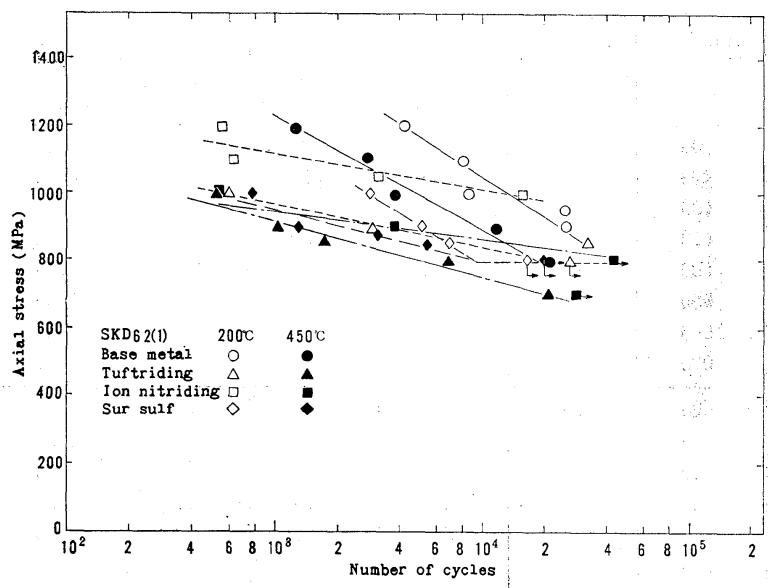

Fig. 5. $S-N$ diagrams of surface hardening treated specimens.

るS-N線図を Fig. 4 亿示す。同図から SKD 62 (1)

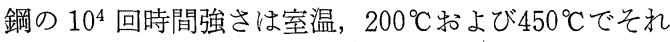
ぞれ $1000.3 \mathrm{MPa}, 1029.7 \mathrm{MPa}$ および $872.8 \mathrm{MPa}$

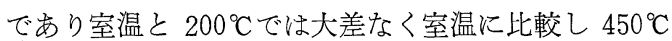
では疲労強度が $13 \%$ 低下している。李た硬さを堌加 （HRC 43. 5 から HRC46 に增加）したSKD62（2)鋼

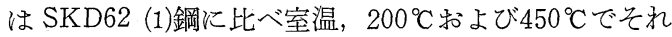
ぞれ $25 \%$ ，10\%斿よび13\%の $10^{4}$ 回時間強さの向上が 認められた．このように硬さを增加したSKD62（2)鋼 の疲労強度が改善されたのは引張強さ, 硬さ等の静的 強度が向上し疲労き裂の発生が遅延したことによるた めと思われる. Fig. 5 には疲労強度改善を目的に行っ たタフトライド $\left(570^{\circ} \mathrm{C} \times 12 \mathrm{Hr}\right)$, イオン窒化 $\left(500^{\circ} \mathrm{C}\right.$ $\times 30 \mathrm{Hr})$ 打よびスルスルフ $\left(565^{\circ} \mathrm{C} \times 10 \mathrm{Hr}\right)$ 処理材 の $200^{\circ} \mathrm{C}$ 和よび $450^{\circ} \mathrm{C}$ の $S-N$ 線図を示すが表面硬化処 理材は試験温度によらず $N<10^{4}$ 回ではいずれも無処 理材（SKD62 (1)鋼）よりも低い時間強度を示した。 SKD62（1)鋼に対するタフトライド，イオン窒化执よ びスルスルフ处理材の $10^{4}$ 回時間強さの低下率は $200^{\circ} \mathrm{C}$

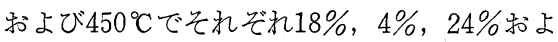
び16\%，6\%，10\%である．表面硬化処理材 の疲労強度の改善効果は前述の通り $N<10^{4}$ 回では認められないが， $N>10^{4}$ 回で母材の $S-N$ 線図と各種表面硬化処理材の $S-N$ 線図 が交差する繰返し数から想像すると表面処理 効果が現れる繰返し数はイオン窒化，スルス ルフおよびタフトライドの順に増加する．表 面硬化処理材の改善効果の現れる繰返し数が 異なるのは試験片表層部の硬さの相違による ためと考光られる。な拈，先に報告した SK $\mathrm{D} 62$ 相当鋼の室温就よび $300^{\circ} \mathrm{C}$ の低サイクル 疲労強度が大差なかったといら事実と今回の 試験結果とを併せて考光ると, 同鋼の低サイ クル疲労強度に及洔す試験温度の影響は最大 引張強さが室温の $90 \%$ 弱程度の $300^{\circ} \mathrm{C}$ では ほとんぞ認められないが，最大引張強さが室 温の $80 \%$ 弱となる $450^{\circ} \mathrm{C} て ゙ は$ 顕著に認められ ることが明らになった．また，改善効果の現 れる繰返し応力 $\left(\sigma_{C}\right)$ は先に実施したタフト ライドを施した平滑試験片の $300^{\circ} \mathrm{C}$ に抢ける 研究で最大引張強さ $\left(\sigma_{B}\right)$.955\%以下である ことを確かめているが，今回の 200 おうび 450 ${ }^{\circ} \mathrm{C}$ に打ける試験でも $\sigma_{C} / \sigma_{B}=0.60$ で略同様 の結果が得られ高温に括いても低サイクル疲 労強度に及湆す表面硬化処理効果が期待でき ることが明らかになった，なお，改善効果の 現れる繰返し応力は形状係数が小さいほど大 なることを確かめている。 つぎに SKD62 (1), 


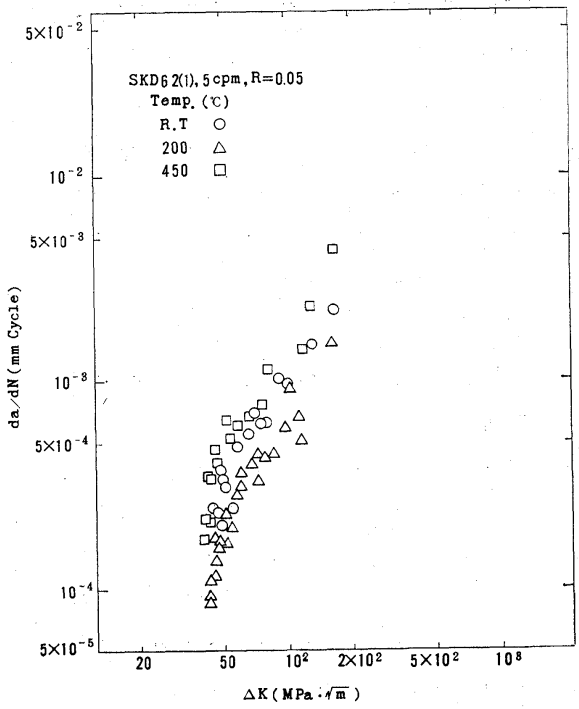

Fig. 6. Crack propagation curves of SKD62 (1).

(2)鋼の疲労き裂進展曲線を Fig. 6 および Fig. 7 亿示 す. $40<\Delta K(\mathrm{MPa} \sqrt{\mathrm{m}})<150$ に和いて両鋼 とも試験 温度が高くなるにつれてき裂進展速度が加速される傾

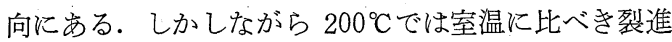
展速度が遅い。この理由については現状明確ではない が酸化物によるき裂開閉挙動等更に詳細な検討が必要 である。また，SKD62 (2)鋼のき裂進展速度はいずれ の温度に拈いてもSKD62（1)鋼よりも幾分加速される 傾向にあるものの大きな相違は認められない，以上の 実験結果から硬さを増加させた試験片の低サイクル疲 労強度の改善は疲労き裂の発生寿命の改善によるとこ ろが大きいことが明らかになった、な和，これ等の研 究結果を参考にし硬さを增加したSKD62 (2)鋼を実金 型に適用し従来の金型に比べ 1.5 倍の命数改善効果が 得られることを確かめている.

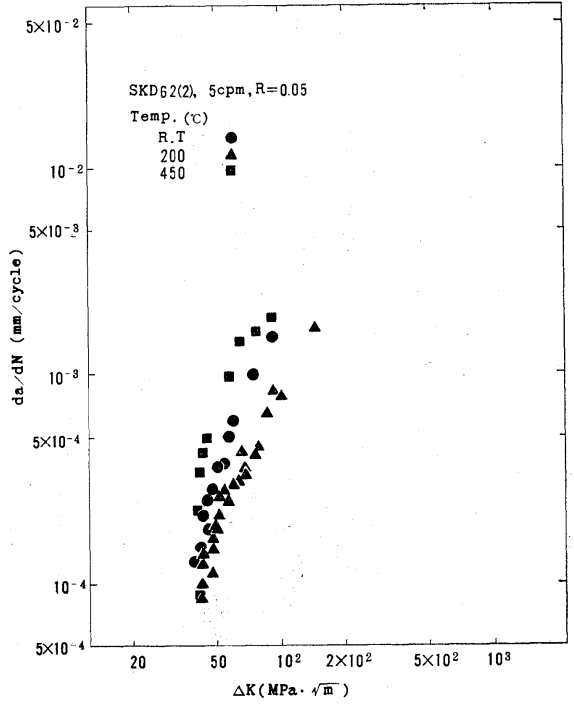

Fig. 7. Crack propagation curves of hardness increased specimens.

\section{$3 \cdot 2$ 熱疲労試験結果}

$400^{\circ} \mathrm{C}, 600^{\circ} \mathrm{C}, 800^{\circ} \mathrm{C}$ 和よび $1000^{\circ} \mathrm{C}$ の加熱温度にお けるき裂発生試験結果を Table II に示す.いずれの 温度に拈いてもき裂は発生し，き裂発生繰返し数は

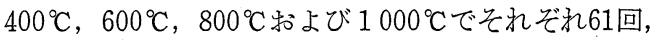
36回，22回および 1 回である.この結果から加熱, 冷 却時における温度差が小さいほどき裂が発生しにくい ことが明らかとなった。なお，加熱温度 $1000{ }^{\circ} \mathrm{C}$ の試 験片は焼割れの現象を示した。裂長さは各温度で最 長繰返し数が異なっているため同一繰返し数での比較 はできないが温度差が小さい湮どさ裂長さは短くなっ ている. 同表にはき裂発生に対する切欠き効果の影響 を検討するために切欠さ比（切欠さ幅対切欠さ深さ） を2 倍に変化させた実験結果を合せて記載しているが，

Table II. Results of thermal fatigue crack initiation tests.

\begin{tabular}{|c|c|c|c|c|c|c|c|c|c|}
\hline Heating system & Cooling system & Notch & $\begin{array}{c}\text { Specimen } \\
\text { No. }\end{array}$ & $\begin{array}{l}\text { Heating } \\
\text { tempera- } \\
\text { ture } \\
\left({ }^{\circ} \mathrm{C}\right)\end{array}$ & $\begin{array}{l}\text { Heating } \\
\text { rate } \\
\left({ }^{\circ} \mathrm{C} / \mathrm{min}\right)\end{array}$ & $\begin{array}{l}\text { Cooling } \\
\text { rate } \\
\left({ }^{\circ} \mathrm{C} / \mathrm{min}\right)\end{array}$ & $\begin{array}{l}\text { Number } \\
\text { of cycles }\end{array}$ & $\begin{array}{l}\text { Number } \\
\text { of cycles } \\
\text { for crack } \\
\text { initiation }\end{array}$ & $\begin{array}{l}\text { Crack } \\
\text { length } \\
(\mathrm{mm})\end{array}$ \\
\hline Gas heating & Water cooling & $5: 1$ & $\begin{array}{l}1 \sim 1 \\
1 \sim 2 \\
1 \sim 3 \\
1 \sim 4 \\
1 \sim 5 \\
1 \sim 6 \\
1 \sim 7 \\
1 \sim 8\end{array}$ & $\begin{array}{r}400 \\
400 \\
600 \\
600 \\
800 \\
800 \\
1000 \\
1000\end{array}$ & $\begin{array}{l}90 \\
90 \\
90 \\
90 \\
90 \\
90 \\
90 \\
90\end{array}$ & $\begin{array}{l}330 \\
330 \\
430 \\
430 \\
530 \\
530 \\
560 \\
560\end{array}$ & $\begin{array}{r}100 \\
100 \\
70 \\
70 \\
50 \\
50 \\
1 \\
1\end{array}$ & $\begin{array}{r}60 \\
62 \\
35 \\
38 \\
20 \\
24 \\
1 \\
1\end{array}$ & $\begin{array}{l}0.01 \\
0.02 \\
0.04 \\
0.03 \\
0.08 \\
0.06 \\
8.2 \\
7.3\end{array}$ \\
\hline$\left(\mathrm{LPG}+\mathrm{O}_{2}\right)$ & (Temp, $\left.5^{\circ} \mathrm{C}\right)$ & $10: 1$ & $\begin{array}{l}2 \sim 1 \\
2 \sim 2 \\
2 \sim 3 \\
2 \sim 4 \\
2 \sim 5 \\
2 \sim 6 \\
2 \sim 7 \\
2 \sim 8\end{array}$ & $\begin{array}{r}400 \\
400 \\
600 \\
600 \\
800 \\
800 \\
1000 \\
1000\end{array}$ & $\begin{array}{l}90 \\
90 \\
90 \\
90 \\
90 \\
90 \\
90 \\
90\end{array}$ & $\begin{array}{l}330 \\
330 \\
430 \\
430 \\
530 \\
530 \\
560 \\
560\end{array}$ & $\begin{array}{r}100 \\
100 \\
70 \\
70 \\
50 \\
50 \\
1 \\
1\end{array}$ & $\begin{array}{r}60 \\
63 \\
40 \\
38 \\
22 \\
20 \\
1 \\
1\end{array}$ & $\begin{array}{l}0.03 \\
0.03 \\
0.06 \\
0.04 \\
0.08 \\
0.07 \\
6.2 \\
6.5\end{array}$ \\
\hline
\end{tabular}




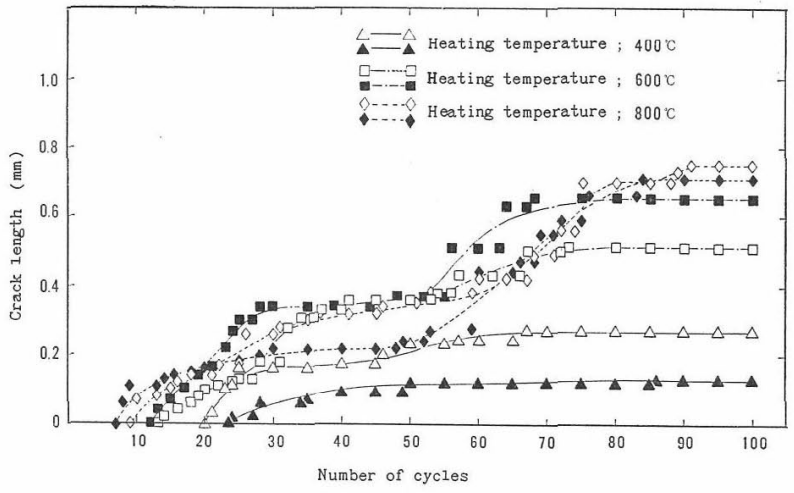

Fig. 8. Thermal fatigue crack propagation curves.

切欠き比が 2 倍程度ではき裂発生に及ぼす切欠きの影 響は活とんど認められない。Fig.8 にはさ裂進展曲線 走す. 加熱温度 $200^{\circ} \mathrm{C}$ では繰返し数 100 回に扣いて き裂が進展しないことを確認している， $400^{\circ} \mathrm{C} て ゙ は$ 約 50回までき裂は進展し50回以後汪とんど進展していな い.一方， $600^{\circ} \mathrm{C}$ おび $800^{\circ} \mathrm{C} て ゙ は$ 約 30 回までき裂は進 展し30回以後50回まで停滞するが50回以降約80回まで 再びき裂は進展しその後はとえど進展しておらず400 ${ }^{\circ} \mathrm{C}$ 進展挙動とは大きく異なっている。この原因は温 度差によるところが大きいものと思われるがき裂の停 滞をはじめとした特異なき裂進展挙動については水冷 却の結果生ずるき裂面の酸化物の挙動等更に詳細な検 討を行らことが必要である，先に平野らはSKD62 相 当鋼の熱衝撃による破壞は温度差を小さくすることに より防止できるとの結果を得ているが，本研究の結果 温度差を小さくすることによりき裂の進展をも遅延さ せ得ることが可能であることが明らかになった。き裂 発生に及ぼす表面硬化処理の影響は温度により異なる

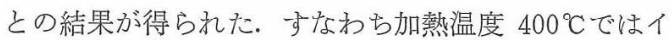
オン空化処理 $\left(530^{\circ} \mathrm{C} \times 30 \mathrm{Hr}\right)$ 時に生じる压縮残留応 力の効果により繰返し数 100 回に积いてき裂は発生し

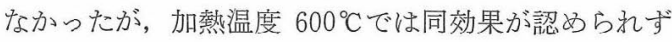
さ裂が発生した。しかもさ裂は無処理材よりも2 倍程 度早く発生し, 同繰返し数に伃いてき裂長さが無処理 材に比べ約 2 倍長い。これはイオン窒化処理によって 試験片表層部が硬化された反面, 切欠き先端部の伸び が低下し割れ感受性が高くなったものと考光る。この ように表面硬化処理は温度によってその効果が左右さ れることが判明したので実金型適用に際しては鏗造采 件等十分考慮したら觉で採用することが望ましい。

\section{$3 \cdot 3$ 破面観察結果}

SKD62 (2)鋼の疲労寿命試験後における $200^{\circ} \mathrm{C}$ の疲 労破面の一例を Fig. 9 に示す。両鋼とも試験温度に よらず疲学き裂は試験片表面から発生して括り進展部 にはストライエーションが支配的に現れている。また，
瘦労破面は表面から $0.3 \sim 0.5 \mathrm{~mm}$ 程度で破 面の大部分は一発破壞面を旺した。なお，表 面硬化処理材も同様な破面形態を示した. SKD62 (1), (2)鋼の室温, $200^{\circ} \mathrm{C}$ 特よび $450^{\circ} \mathrm{C}$ に 敃ける疲労き裂進展部の破面にはいずれの温 度に和いてもストライエーションが支配的に 認められた. 加熱温度 $400^{\circ} \mathrm{C}$ 㧊よび $600^{\circ} \mathrm{C}$ の熱 疲労き裂進展部の破面を Fig. 10 に示す。き 裂は粒内を通って進展し，乙ま状模様が特徵 的に認められた。また，試験片表面のき裂は 粒内を進展し，き裂先端部が鋭いことを確認 している。このように熱疲労さ裂が粒内を通 って進展する現象は平野，小林らが熱間鍛造

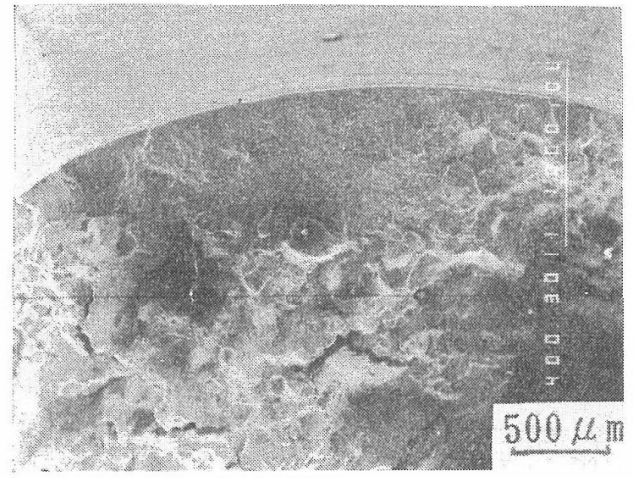

(a) Initiation

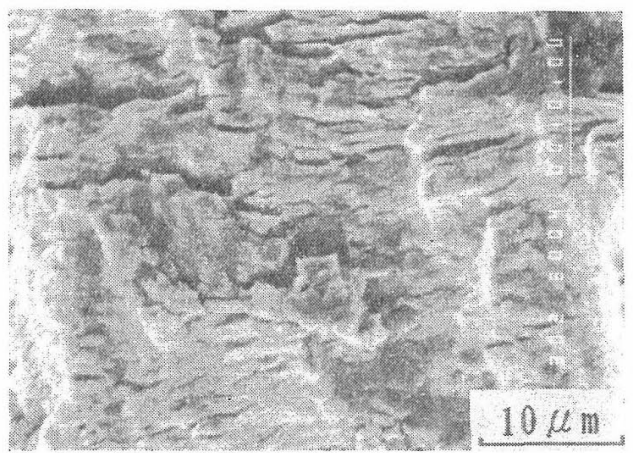

(b) $0.5 \mathrm{~mm}$ from initiation

SKD62 (2) $200^{\circ} \mathrm{C}$ $\sigma=1274.9 \mathrm{MPa}, \quad N=3890$

Fig. 9. Fatigue fracture surfaces.

用型鋼 (SKD62 鋼) について CT 試験片を用い熱衝 撃試験を行った結果，き裂が粒界を沿って進展したと の報告とは異なっているがこれは試験条件，試験材の 相違によるものと思われる。Fig. 11 には実機に和い て 1000 回使用した後, 液体窒素中で強制的に破壞さ せたギャ・リバース下金型のコーナ $\mathrm{R}$ 部の表面の一部 㘧よび破面を示す， R 部表面には熱疲学により生じた と思われる亀甲状の割れが多数認められ，き裂進展部 の破面には試験片と同様なしま状模様が特徽的に認め 


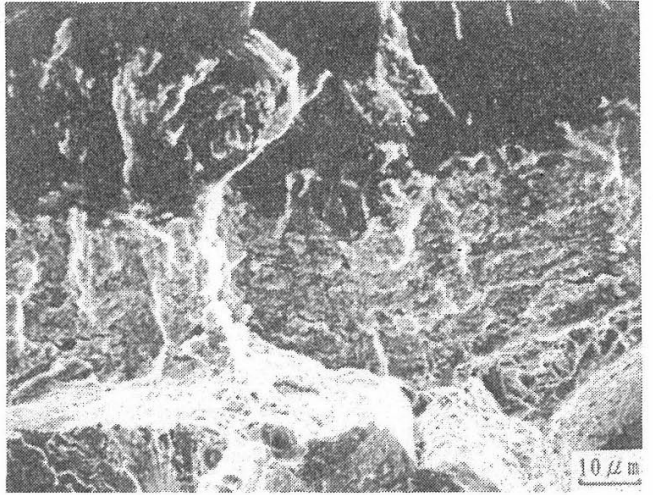

(a) Heating temperature; $400^{\circ} \mathrm{C}$, Number of cycles; 100

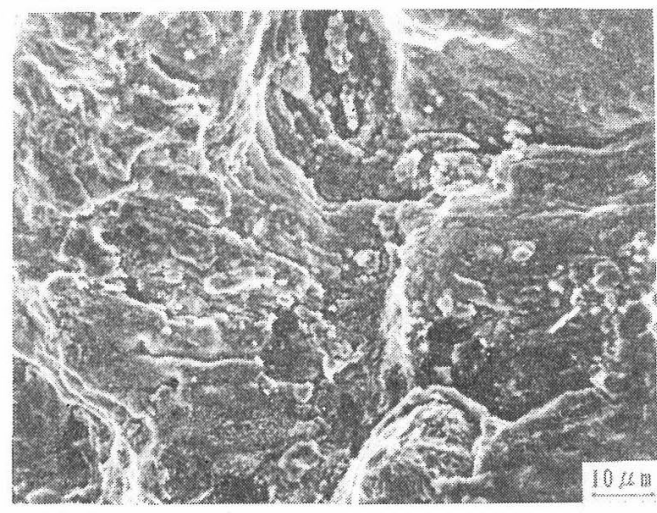

(b) Heating temperature; $600^{\circ} \mathrm{C}$, Number of cycles; 100

Fig. 10. Thermal fatigue fracture surfaces of specimens.

られている、また，金型断面の智先端は鋭く，粒内 を通って進展していることを認めている．破面観察の 結果から本研究で実施した熱疲労試験は実金型の熱疲 労挙動を非較的良く再現している試験方法のように思 われるが, 今後更に熱疲労裂の発生限界温度の把握 と同時に熱疲労き裂の発生扝よび進展挙動に及ぼす静 的応乃の効果についての検討が必要と思われる.

\section{4 結言}

熱間鍛造用型鋼について低サイクル疲学強度および 疲労き裂進展速度に及ぼす試験温度, 硬さおよび各種 表面硬化処理の影響を把握する目的で低サイクル疲労 試験を実施し，また同鋼の熱痕労挙動について検討し た結果, 次の結論を得た。

(1) SKD62 (1)鋼の低サイクル疲労寿命試験の結果,

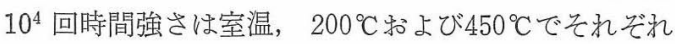
$1000.3 \mathrm{MPa}, 1029.7 \mathrm{MPa}$ および $872.8 \mathrm{MPa}$ であ

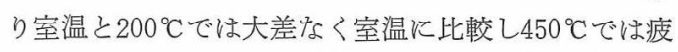
労強度が13\%低下した. (2)硬さを增加（HRC 43.5 か ら HRC 46) することにより室温, $200{ }^{\circ} \mathrm{C}$ 和よび $450^{\circ} \mathrm{C}$ で疲労強度がそれぞれ $25 \%$ ，10\% 拉よび 13\% 向上し た.

（3）表面硬化処理材の疲労強度はいずれの温度に打

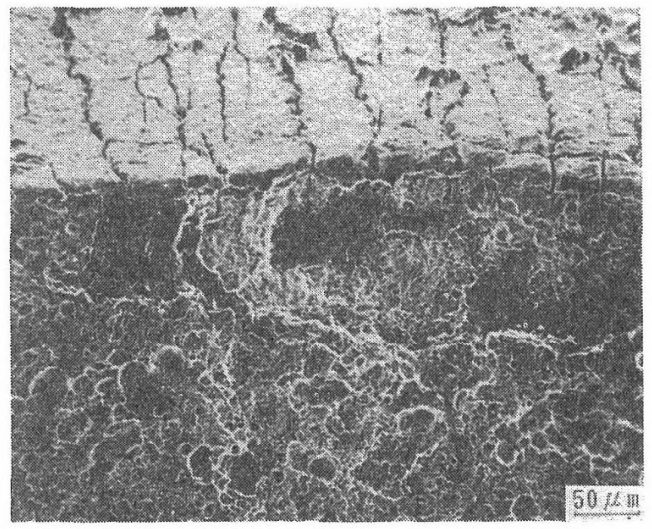

(a) Initiation area

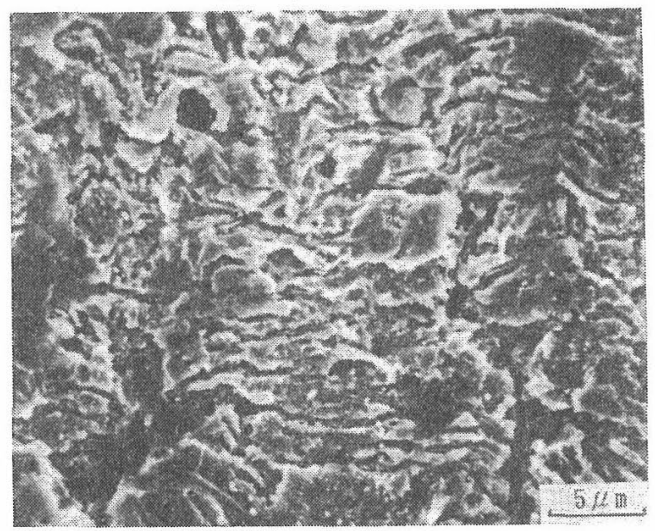

(b) $0.75 \mathrm{~mm}$ from surface

Fig. 11. Thermal fatigue fracture surface of hot forging die.

いても SKD62 (1)鋼よりも低く疲労強度の改善効果が 現れるのは $N>10^{4}$ 回以上飞执いてである。また，疲 労強度の改善効果が最も早く現れる表面処理はイオン 窒化で続いてスルスルフ，タフトライドの順である。

(4) 疲労き裂進展速度は温度が高くなると加速され る傾向に第る。なた，硬さを增加しても裂進展速度 には洼とんど影響を及添さない。

（5）熱疲労き裂は温度 $400^{\circ} \mathrm{C} \sim 1000^{\circ} \mathrm{C}$ のいずれに和 いても発生するが温度差が小さくなるほどき裂発生に 要する繰返し数は大となる。

（6）熱痕労き裂発生に及ぼすイオン窒化処理の効果

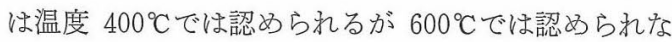
w.

（7）熱疲労き裂は温度 $200^{\circ} \mathrm{C}$ では進展しないが $400^{\circ} \mathrm{C}$ 以上で進展する。しかしながら，温度差を小さくする ことによりき裂の進展を遅延させることが叮能である。

（8）破面観察の結果, 疲労き裂進展部の破面には試 験温度，硬さによらずストライエーションが支配的に 認められた。熱疲労き裂愔内通って進展し，破面 にはしま状模様が特徴的に認められ，実金型の熱疲労 破面と良い対応を示した。 
な拈，工技院機械技術研究所平野一美氏より本研究 の結果に対し有益なコメントを得た. 特に記して謝意 を表する。

（昭和61年 6 月 12 日 第 5 回フラクトグラフィシンポジウムにて講濱）

\section{参 考 文 献}

1）江原隆一郎, 井上慶之助, 䆶田勝昭, 材料, 29, 599
(1980).

2) R. Ebara and K. Kubota, Steel Forgings ASTM STP 903, 583 (1986).

3）江原隆一郎, 窪田勝昭, 塑性と加工, 23, 977 (1982).

4) 平野一美, 小林英男, 中沢 一, 材料, 27, 104 (1977).

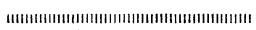

墨 諳平

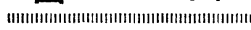

$$
\text { “光之材料” }
$$

住友電気工業株式会社（編）

（1986年，共立出版(株)発行，B 6 判，211ページ，1800円）

最近, 光ディスク，光通信をはじめ光利用について研究開発，また実用の面で非常に大きな進歩をとげ，さら に今後, 拡大する傾向にある状況に㨟いて, 本著書はオプトェレクトロニクス分野に的を絞って, システム・デ バイスの中でどのような形で光素子が使用されているかを解説している．さらに，専門外の人にも分りやすいよ らに, 専門用語については必要に応じて解説されているので, 理解に役立っている.

さて, 本書の内容であるが, 可視 LED や赤外 LED, 受光素子の説明にはじまり, 情報表示（ディスプレイ） デバイスとしての LED， EL，EC や液晶ディスプレイについて平易に解説されて和り，入門書としての役割を 果している.

さらに, 最後の部分では光ディスク, 光通信, レーザー加工, 医療への応用等, 利用面について頁をさいてお り，ある意味で，本書の内容に执いてバランスをとっていると言兄よう.

(川崎重工業(株)技術研究所 堀川武) 